\section{SHORT COURSE NEWS}

\section{Short Courses Offered at MRS Fall Meeting}

Vivienne Harwood Mattox

MRS Short Course Manager

The MRS short course program to be offered at the 1986 MRS Fall Meeting will consist of 23 courses, including nine new courses. This number of courses represents a significant expansion of the program for this meeting. The program will cover the latest in emerging materials technology and related topics in addition to some of the most popular review courses on materials preparation, fabrication, characterization and utilization. Some of the courses on epitaxial growth, thin films, and plasma processing of semiconductors are designed so that together they present a comprehensive treatment of a diverse subject. (See the ad elsewhere in this issue of the BULLETIN.)

The first "stand-alone" short course program is scheduled for October 1-3, 1986 in Albuquerque, NM. A "stand-alone" program is one that is not being held in conjunction with a technical meeting. Two intensive three-day short courses are being cosponsored by MRS and the University of New Mexico. The topics are: "Characterization of Powders and Porous Materials" and "Plasma Modeling, Pattern Transfer, and Nonintrusive Plasma Diagnostics for IC Fabrication." Use of the laboratory facilities of the university, including the UNM Powders and Granular Materials Laboratory will add a new dimension to these short courses. This program has been developed with the valuable support and enthusiasm of the MRS New Mexico Section. It is hoped that other programs involving the use of laboratory facilities for demonstrations and "hands-on" experience will be developed in 1987 .

The on-site short course program continues to receive in terest and support from industry. The last issue of the BULLETIN listed the current roster of MRS short courses available for on-site presentation on an instructor-avajlable basis. Several new courses are being developed for the 1987 Spring Meeting.

If you are interested in more detailed information concerning future plans for the short course program, contact the MRS Short Course Manager, Vivienne Harwood Mattox; telephone (505) 294-9532. MRS invites comments and suggestions for the short course program.

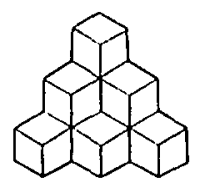

\section{Slate of Candidates Announced For 1987 MRS Offices}

In his capacity as chairman of the MRS Nominating Committee, Elton N. Kaufmann (Lawrence Livermore National Laboratory) has announced that the committee and the MRS Council have concluded the nomination and approval process for a slate of candidates who will run for 1987 MRS offices in the 1986 Society election. Below are listed the individuals who will appear on the ballot to be distributed shortly to MRS members.

First Vice President

and President-Elect

(1-year term)

John E. E. Baglin (IBM - Yorktown Heights)

Clifton W. Draper (AT\&T Technologies)

Second Vice President

(1-year term)

R. P. H. Chang (Northwestern University)

Paul S. Peercy (Sandia National Laboratories)

\section{Secretary}

(2-year term)

David R. Campbell (IBM -East Fishkill)

Julia M. Phillips (AT\&T Bell Laboratories)

Treasurer

(2-year term)

Susan M. Kelso (Xerox PARC)

James B. Roberto (Oak Ridge National Laboratory)

\section{Councillor}

(3-year term)

( 5 seats to be filled)

John K. Bates (Argonne National Laboratory)

David K. Biegelsen (Xerox PARC)

Clifton W. Draper (AT\&T Technologies)

Rodney C. Ewing (University of New Mexico)

Robert A. Huggins (Stanford University)

Herbert H. Johnson (Cornell University)

Ross A. Lemons (Los Alamos National Laboratory)

Paul S. Peercy (Sandia National Laboratories)

John M. Poate (AT\&T Bell Laboratories)

Richard L. Schwoebel (Sandia National Laboratories)

C. W. (Woody) White (Oak Ridge National Laboratory)

Biographical information and statements by the candidates will be enclosed with the mail ballots. Election procedures require that the total number of members of the MRS Council (officers plus councillors) be maintained at 21 . It has not been unusual for officers to be elected as councillors and vice versa in the past. When such a dual role occurs, the number of new councillors elected will be adjusted to maintain the total representation at 21 .

Kaufmann emphasized that now that the work of the Nominating Committee is done, MRS members must exercise their right to determine the outcome of the election. "All the candidates are excellent and will serve the Society well if elected," said Kaufmann, "but each has his/her own views on the directions MRS should follow and the choice of the membership will control what paths we pursue." 